\title{
Prevention of Nausea and Vomiting: Methods and Utility after Surgery in Cancer Patients?
}

\author{
Mehdi Dehghani Firoozabadi ${ }^{1}$, Hossein Rahmani ${ }^{2,3 *}$
}

\begin{abstract}
Most cancer patients experience nausea and vomiting after surgery. Today, many methods of treatment have been developed and used for the control of such symptoms. The most important are drug therapy, relaxation, oxygen therapy and gas therapy. In addition, dexamethasone, massage therapy and using a Venturi mask have also proven effective. Due to the nature of gas consumption which leads to nausea it is recommended that use of $\mathrm{N2O}$ in the operating room be avoided or applied in combination with oxygen or other gases with fewer complications.
\end{abstract}

Keywords: Cancer surgery - nausea - vomiting - control measures - oxygen - relaxation - N2O

Asian Pac J Cancer Prev, 16 (7), 2629-2635

\section{Introduction}

Cancer has increased dramatically in developed as well as developing countries. Unfortunately most of cancer patients need to surgery and the most common and annoying problems after surgery is nausea and vomiting (PONV) (Gan , 2006; Korjuo et al., 2010). Despite the treatment with antiemetic drugs which occurred in 20 $70 \%$ cases (Habib, 2004). PONV has been so annoying for cancer patients that could prevent them from continuing treatment. Also significant cost a lot due to need for a long hospitalization of the patient, that economically it was costly for society (Gan, 2006). This condition depended on the type of cancers and surgery could be more common, to treat the cancer.

Among the known side effects of nausea and vomiting were: dehydration, electrolyte imbalance, Stretch stitches and opening it, venous hypertension, bleeding and rarely, esophageal perforation (Rowbotham, 2005; Gan, 2006). Aaround the world, many studies have been done for the prevention and treatment of PONV but still no effective and specific performance is available in this area. (Bhatnagar et al., 2005).

One of the factors that exists in contribute to the increased incidence of nausea and vomiting after surgery was the stimulation increasing of vag more than expected because of sympathetic inhibition.Drop in blood pressure , Additives such as vascular contractile, neostigmine and epioeds to anesthetic agent were the other important factors that increases the chance of nausea and vomiting. Drop in blood pressure caused brainstem ischemia which led to stimulation of the vomiting center in the brain stem.
Drop in blood pressure also caused of intestinal ischemia and the release of substances causing nausea Such as serotonin. The use of high concentrations of oxygen with brainstem ischemia and intestines could cause in decreasing nausea and vomiting with mechanism which has been mentioned (Bhatnagar et al., 2005).

Recently, many treatment methods have been developed and used for the control of post operation nausea and vomiting in cancer patients. The aim of the present study was to review methods of reduce post operation nausea and vomiting in cancer patients.

\section{Effects of Relaxation on Post Operation of Nausea and Vomiting in Cancer Patients}

So far a lot of studies and considerable research have been done in order to find more suitable ways to control nausea which caused by surgery in cancer patients. The appropriate method was the use of antiemetic for nausea and vomiting. But these drugs, depending on the type of cancer and needed surgery, were not effective for all patients and often cause unpleasant side effects. In recent decades relaxation therapies have devoted special attention for post operation nausea and vomiting in cancer patients.

In studies that have tested the effect of massage therapy for post operation, nausea and vomiting in cancer patients has showed that massage therapy which has had magical effect in reducing nausea and vomiting (Ratehanon 2011; Kearney, 2012; Kim, 2013). The foot and hand massage for 7 days after surgery has reduced till $30 \%$ of nausea and vomiting of cancer patients (Hickok et al., 2012).

In a study it showed that massage therapy has reduced

${ }^{1}$ Department of Anesthesiology, Shahid Sadoughi University of Medical Sciences, Yazd, ${ }^{2}$ Departments of Toxicology, Shahreza Branch, Islamic Azad University, Shahreza, ${ }^{3}$ Medical Research Center, Jundishapur Health Development Co, Tehran, Iran *For correspondence:r.h1989@yahoo.com 
pain, discomfort, nausea, fatigue, and conversely, has caused to notice relaxation response, and life force has been increased (Lefebvre, 2005). Ten-minute foot massage led to relaxation and ultimately improves the subjective experience of pain, nausea, and decreased heart rate (Houston et al., 2004). Also the 25-minute training of relaxation by using audio tape has been effective in reducing nausea and vomiting in cancer patients (Viswanathan et al., 2006). Gentle back massages have led to relaxation, emotional health, improved appetite and reduced nausea in cancer patients (Lapoint et al., 2006). Lapoint in his study has understood that acupuncture has anti-nausea effects, but the results were not statistically significant (Brandt, 2005).

Based on the above studies, it can be stated that, depending on the type of surgery that performed in cancer patients, massage therapy has been an effective method for reducing nausea and vomiting. This method caused to reduce mental relaxation-intellectual and pain in patients with low cost and can be used as an adjunct to deal with PONV (Table 1).

\section{Effect of Drug Therapy on Post Operation of Nausea And Vomiting in Cancer Patients}

Many drugs used for prevention and treatment of PONV after surgery in cancer patients that the most important of them included antihistamines, phenothiazines, and Butyrophenone and anticholinergics. The usage of these drugs due to their effects associated with limitations (Ekangaki et al., 2005). For this reason, researchers were searching for compounds which would be more effective with fewer side effects. Generally midazolam and benzodiazepine drugs have been the most common type of drugs which used as premedication before surgery with addition to the anti-anxiolytic effect, especially they were effective drugs for nausea and vomiting in post operation in cancer patients (Ayala, 2012). The effect of midazolam premedication with injection has been demonstrated in reducing the incidence and severity of post-operative nausea and vomiting in cancer patients (Vigil et al., 2012; Canbay et al., 2013).

About the effect of betamethasone several studies have done on reducing nausea and vomiting with variety of patients such as cancer patients that we pointed out the most valid of them. (Isik, 2013) In one study it has shown that the rate of post operation nausea and vomiting in cancer patients that had received betamethasone reduced till 30\% compared to control group (Dietrich et al., 2011). Oral clonidine in the supply of medicines has considered preventing of nausea and vomiting after surgery. Prescription oral clonidine 1 hour before surgery for breast cancer patients has reduced the amount and severity of nausea and vomiting after the operation (Ruthstrom et al., 2012). Clonidine significantly reduced the frequency and the number of vomiting in cancer patients after surgery than metoclopramide (Coskun et al., 2013) in the comparative study of clonidine, betamethasone,

Table 1. Effects of Relaxation on Post-operation Nausea and Vomiting in Cancer Patients

\begin{tabular}{|c|c|c|c|c|}
\hline Authur & $\begin{array}{l}\text { Sample } \\
\text { size }\end{array}$ & Design/population & method & Outcome \\
\hline $\begin{array}{l}\text { Kearney et al., } \\
2012\end{array}$ & 114 & $\begin{array}{l}\text { Women with breast cancer require } \\
\text { surgery }\end{array}$ & $\begin{array}{l}\text { Case- } \\
\text { control }\end{array}$ & $\begin{array}{l}\text { Massage therapy has had a great effect in reduc- } \\
\text { ing nausea and vomiting in patients }\end{array}$ \\
\hline $\begin{array}{l}\text { Ratehanon et } \\
\text { al., } 2011\end{array}$ & 48 & $\begin{array}{l}\text { Men with lung cancer requiring } \\
\text { surgery }\end{array}$ & $\begin{array}{l}\text { Case- } \\
\text { control }\end{array}$ & $\begin{array}{l}\text { message therapy has been effective In reducing } \\
\text { nausea and vomiting in cancer patients }\end{array}$ \\
\hline $\begin{array}{l}\text { Kim et al., } \\
2013\end{array}$ & 90 & $\begin{array}{l}\text { Gastric cancer patients in different } \\
\text { age and sex groups }\end{array}$ & $\begin{array}{l}\text { Case- } \\
\text { control }\end{array}$ & $\begin{array}{l}\text { Massage therapy has effected in reducing nausea } \\
\text { and vomiting in cancer patients }\end{array}$ \\
\hline $\begin{array}{l}\text { Hickok et al., } \\
2012\end{array}$ & 120 & $\begin{array}{l}\text { Cancer patients over } 12 \text { years in } \\
\text { both genders }\end{array}$ & $\begin{array}{l}\text { Case- } \\
\text { control }\end{array}$ & $\begin{array}{l}\text { Foot and hand massage till } 7 \text { days after surgery } \\
\text { has reduced nausea and vomiting till } 30 \% \text { for } \\
\text { cancer patients }\end{array}$ \\
\hline $\begin{array}{l}\text { Houston et al., } \\
2004\end{array}$ & 75 & $\begin{array}{l}\text { Cancer patients in different age } \\
\text { groups and sex }\end{array}$ & $\begin{array}{l}\text { Cease } \\
\text { control }\end{array}$ & $\begin{array}{l}\text { Ten-minute foot massage has been effective in } \\
\text { reducing nausea and vomiting in cancer patients }\end{array}$ \\
\hline $\begin{array}{l}\text { Lefebvre, } \\
2005\end{array}$ & 120 & $\begin{array}{l}\text { Women with breast cancer has been } \\
\text { undergoing radiotherapy for over } 20 \\
\text { years }\end{array}$ & $\begin{array}{l}\text { Clinical } \\
\text { trial }\end{array}$ & $\begin{array}{l}\text { Massage therapy has been effective in reducing } \\
\text { nausea }\end{array}$ \\
\hline $\begin{array}{l}\text { Yusrizal et al., } \\
2006\end{array}$ & 56 & $\begin{array}{l}\text { Cancer patients in different groups } \\
\text { of cancer in both sexes }\end{array}$ & $\begin{array}{l}\text { Cease } \\
\text { control }\end{array}$ & $\begin{array}{l}\text { Behavioral therapies, cognitive, relaxation and } \\
\text { visualization has not had any effect on nausea and } \\
\text { vomiting in cancer patients }\end{array}$ \\
\hline $\begin{array}{l}\text { Viswanathan } \\
\text { et al., } 2006\end{array}$ & 112 & $\begin{array}{l}\text { Cancer patients have normal hearing } \\
\text { in both genders }\end{array}$ & $\begin{array}{l}\text { Cease } \\
\text { control }\end{array}$ & $\begin{array}{l}\text { Use relaxation techniques has been effective to } \\
\text { reduce audio tape delayed nausea and vomiting in } \\
\text { cancer patients }\end{array}$ \\
\hline $\begin{array}{l}\text { Lapoint et al., } \\
2006\end{array}$ & 44 & $\begin{array}{l}\text { patients under chemotherapy over } 20 \\
\text { years in both genders }\end{array}$ & $\begin{array}{l}\text { Cease } \\
\text { control }\end{array}$ & $\begin{array}{l}\text { The use of acupuncture has not been statistically } \\
\text { significant in patients undergoing chemotherapy } \\
\text { antiemetic effects }\end{array}$ \\
\hline $\begin{array}{l}\text { Brandt et al., } \\
2005\end{array}$ & 87 & $\begin{array}{l}\text { Chemotherapy in both genders in } \\
\text { different types of cancer }\end{array}$ & $\begin{array}{l}\text { Cease } \\
\text { control }\end{array}$ & $\begin{array}{l}\text { Gentle back massage to has been effective in } \\
\text { reducing nausea in patients with cancer receiving } \\
\text { chemotherapy }\end{array}$ \\
\hline
\end{tabular}


Dexamethasone has had the greatest impact in reducing nausea and vomiting in cancer patients (Harter, 2002). Although dexamethasone had antiemetic effect in patients with cancer (Nortcliffe et al., 2003; Madan et al., 2005; Chen et al., 2006; Ayala et al., 2012), the mechanism of the action have not discovered. But perhaps apply its effectiveness s by preventing central prostaglandin.

Another hypothesis has suggested these drugs by reducing the return $5 \mathrm{HT}$ in the central nervous system or performed this procedure by creating a barrier permeability of blood-brain to serum of proteins (Ekangaki, 2005). Although most studies of PONV have been under general anesthesia population However, in despite of other population groups also has been shown the use of dexamethasone to reduce the incidence of PONV (Wakim et al., 2006). In a case study, the effect of dexamethasone $8 \mathrm{mg}$ have evaluated with placebo hysterectomy, it showed that dexamethasone decreased in the incidence of PONV with compare to the control group in this population (Marro et al., 2006). In the study of clinical trial was a randomized of PONV in women who had undergone surgery under spinal anesthesia; in both groups the dexamethasone and granisetron (Granisetron) were compared. Dexamethasone significantly has reduced immediately the incidence of PONV and 24 hours after surgery with compared to gzaniztron (Denehy et al., 2005). Finally, it can be concluded that the prescription of dexamethasone in patients with cancer dramatically has reduced the incidence of nausea and vomiting after surgery, and it did not have any specific side effect, however, in order to extend its application to other population groups, it requires further studies (Table 2).

Table 2. Impact of Drug Therapy on Post Operation Nausea and Vomiting in Cancer Patients

\begin{tabular}{|c|c|c|c|c|}
\hline Authur & $\begin{array}{l}\text { Sample } \\
\text { size }\end{array}$ & Design/population & method & Outcome \\
\hline $\begin{array}{l}\text { Ekangaki et } \\
\text { al., } 2005\end{array}$ & 450 & $\begin{array}{l}\text { Cancer patients receiving } \\
\text { chemotherapy for various age } \\
\text { and sex groups }\end{array}$ & $\begin{array}{l}\text { Case } \\
\text { control }\end{array}$ & $\begin{array}{l}\text { Antihistamines, phenothiazines, and Butyrophenone and } \\
\text { anticholinergics PONV to deal with the complications of } \\
\text { chemotherapy }\end{array}$ \\
\hline $\begin{array}{l}\text { Canbay et } \\
\text { al., } 2013\end{array}$ & 48 & $\begin{array}{l}\text { Cancer patients undergoing sur- } \\
\text { gery with age wise \&sex wise }\end{array}$ & $\begin{array}{l}\text { Case } \\
\text { control }\end{array}$ & $\begin{array}{l}\text { The effect of premedication with midazolam injection } \\
\text { have been demonstrated in reducing the incidence and } \\
\text { severity of post operation nausea and vomiting in cancer } \\
\text { patients }\end{array}$ \\
\hline $\begin{array}{l}\text { Vigil et al., } \\
2012\end{array}$ & 14 & $\begin{array}{l}\text { Cancer patients undergoing sur- } \\
\text { gery with age wise \& sex wise }\end{array}$ & $\begin{array}{l}\text { Clinical } \\
\text { trial }\end{array}$ & $\begin{array}{l}\text { Continuous infusion of midazolam was more has been } \\
\text { effective in comparison with ondansetron for the pre- } \\
\text { vention of nausea and vomiting in cancer patients }\end{array}$ \\
\hline $\begin{array}{l}\text { Isik et al., } \\
2013\end{array}$ & 60 & $\begin{array}{l}\text { Cancer patients undergoing } \\
\text { surgery aged } 20-40 \text { years in both } \\
\text { sex }\end{array}$ & $\begin{array}{l}\text { Case- } \\
\text { control }\end{array}$ & $\begin{array}{l}\text { Betamethasone has been effective in the prevention of } \\
\text { nausea and vomiting in patients after surgery }\end{array}$ \\
\hline $\begin{array}{l}\text { Dietrich et } \\
\text { al., } 2011\end{array}$ & 42 & $\begin{array}{l}\text { Men with prostate cancer aged } \\
25-70 \text { years }\end{array}$ & $\begin{array}{l}\text { Clinical } \\
\text { trial }\end{array}$ & $\begin{array}{l}\text { Postoperative nausea and vomiting in cancer patients } \\
\text { have reduced receiving betamethasone to } 30 \% \text { with } \\
\text { compared to control groups }\end{array}$ \\
\hline $\begin{array}{l}\text { Ruthstrom } \\
\text { et al., } 2012\end{array}$ & 54 & Women with breast cancer & $\begin{array}{l}\text { Clinical } \\
\text { trial }\end{array}$ & $\begin{array}{l}\text { Clonidine prescription orally } 1 \text { hour before surgery for } \\
\text { breast cancer patients has caused to reduce the amount } \\
\text { and severity of nausea and vomiting }\end{array}$ \\
\hline $\begin{array}{l}\text { Coskun et } \\
\text { al., } 2013\end{array}$ & 85 & $\begin{array}{l}\text { Cancer patients undergoing } \\
\text { surgery for various age and sex } \\
\text { groups }\end{array}$ & $\begin{array}{l}\text { Case- } \\
\text { control }\end{array}$ & $\begin{array}{l}\text { Clonidine with comparison to metoclopramide has re- } \\
\text { duced the frequency of metoclopramide and the number } \\
\text { of vomiting after surgery in cancer patients }\end{array}$ \\
\hline $\begin{array}{l}\text { Harter, } \\
2002\end{array}$ & 320 & $\begin{array}{l}\text { Cancer patients receiving } \\
\text { chemotherapy for various age } \\
\text { and sex groups }\end{array}$ & $\begin{array}{l}\text { Pro- } \\
\text { spective }\end{array}$ & $\begin{array}{l}\text { Dexamethasone in patients with cancer who were under- } \\
\text { going chemotherapy has had anti-nausea effects }\end{array}$ \\
\hline $\begin{array}{l}\text { Chen et al., } \\
2006\end{array}$ & 600 & $\begin{array}{l}\text { candidate patients surgery with } \\
\text { age wise \& sex wise }\end{array}$ & $\begin{array}{l}\text { Cease- } \\
\text { control }\end{array}$ & $\begin{array}{l}\text { Dexamethasone has decreased the amount of PONV } \\
\text { after surgery in patients }\end{array}$ \\
\hline $\begin{array}{l}\text { Madan, et } \\
\text { al., } 2005\end{array}$ & 150 & $\begin{array}{l}\text { Cancer patients undergoing } \\
\text { surgeryaged } 14-65 \text { years both } \\
\text { genders }\end{array}$ & $\begin{array}{l}\text { De- } \\
\text { scrip- } \\
\text { tive }\end{array}$ & $\begin{array}{l}\text { Dexamethasone has been effective in preventing post } \\
\text { operation nausea and vomiting in cancer patients }\end{array}$ \\
\hline $\begin{array}{l}\text { Nortcliffe } \\
\text { et al., } 2003\end{array}$ & 540 & $\begin{array}{l}\text { candidate Patients undergoing } \\
\text { surgery for various age and sex } \\
\text { groups }\end{array}$ & $\begin{array}{l}\text { Analyti- } \\
\text { cal }\end{array}$ & $\begin{array}{l}\text { Dexamethasone alone or in combination with other } \\
\text { compounds Anti-nausea surgery has reduced the rate of } \\
\text { PONV among different populations }\end{array}$ \\
\hline $\begin{array}{l}\text { Wakim et } \\
\text { al., } 2006\end{array}$ & 1500 & $\begin{array}{l}\text { Dissatisfaction of patients with } \\
\text { PONV }\end{array}$ & $\begin{array}{l}\text { Cease } \\
\text { control }\end{array}$ & $\begin{array}{l}\text { to reduce the incidence of PONV has shown by using } \\
\text { dexamethasone }\end{array}$ \\
\hline $\begin{array}{l}\text { Marro et } \\
\text { al., } 2006\end{array}$ & 82 & $\begin{array}{l}\text { Abdominal hysterectomy under } \\
\text { epidural morphine }\end{array}$ & $\begin{array}{l}\text { Clinical } \\
\text { trial }\end{array}$ & $\begin{array}{l}\text { Dexamethasone has shown significantly decreasing in } \\
\text { the incidence of PONV compared with the control group }\end{array}$ \\
\hline $\begin{array}{l}\text { Denehy et } \\
\text { al., } 2005\end{array}$ & 115 & $\begin{array}{l}\text { Women who had undergone } \\
\text { surgery under spinal anesthesia }\end{array}$ & $\begin{array}{l}\text { Clinical } \\
\text { trial }\end{array}$ & $\begin{array}{l}\text { Dexamethasone has reduced the incidence of PONV } \\
\text { immediately and } 24 \text { hours after surgery compared with } \\
\text { gezaniztrone }\end{array}$ \\
\hline
\end{tabular}


Mehdi Dehghani Firoozabadi and Hossein Rahmani

Table 3. Effect of Oxygen Therapy on Post Operation Nausea and Vomiting in Cancer Patients

\begin{tabular}{|l|c|l|l|l|}
\hline \multicolumn{1}{|c|}{ Authur } & $\begin{array}{c}\text { Sample } \\
\text { size }\end{array}$ & \multicolumn{1}{|c|}{ Design/population } & Method & \multicolumn{1}{|c|}{ Outcome } \\
\hline $\begin{array}{l}\text { Lindbohm } \\
\text { et al., 2007 }\end{array}$ & 84 & $\begin{array}{l}\text { Women with breast cancer over 30 } \\
\text { years, requiring surgery }\end{array}$ & $\begin{array}{l}\text { Case- } \\
\text { control }\end{array}$ & $\begin{array}{l}\text { The incidence of PONV has reduced by 19\% } \\
\text { oxygen }\end{array}$ \\
\hline $\begin{array}{l}\text { Bynner et } \\
\text { al., 2005 }\end{array}$ & 95 & $\begin{array}{l}\text { Gastric cancer patients in different age } \\
\text { groups and sex who need surgery }\end{array}$ & $\begin{array}{l}\text { Case- } \\
\text { control }\end{array}$ & $\begin{array}{l}\text { The group that had received 80\% oxygen com- } \\
\text { pared with control group had 50\% reduction }\end{array}$ \\
\hline $\begin{array}{l}\text { Purhonen } \\
\text { et al., 2003 }\end{array}$ & 35 & $\begin{array}{l}\text { Women with breast cancer at different } \\
\text { ages who require surgery. }\end{array}$ & $\begin{array}{l}\text { Case- } \\
\text { control }\end{array}$ & $\begin{array}{l}\text { comparison between 30 and 50 percent oxygen } \\
\text { therapy in patients with breast surgery only had a } \\
\text { small effect on nausea and not on vomiting }\end{array}$ \\
\hline $\begin{array}{l}\text { Jaakkola, } \\
\text { 2009 }\end{array}$ & 55 & $\begin{array}{l}\text { Women with cervical cancer who } \\
\text { requires surgery in different ages }\end{array}$ & $\begin{array}{l}\text { Case- } \\
\text { control }\end{array}$ & $\begin{array}{l}80 \% \text { inspired oxygen during and 6 hours after } \\
\text { surgery has had significant in decreasing the } \\
\text { incidence of nausea and vomiting than the control } \\
\text { group. }\end{array}$ \\
\hline $\begin{array}{l}\text { Kreisarin et } \\
\text { al., 2013 }\end{array}$ & 75 & $\begin{array}{l}\text { Patients with various cancers in both } \\
\text { sexes aged over 12 years and below 70 } \\
\text { years, who require surgery. }\end{array}$ & $\begin{array}{l}\text { Case- } \\
\text { control }\end{array}$ & $\begin{array}{l}80 \% \text { oxygen prescription during surgery and 6 } \\
\text { hours after surgery, has had high impact and } \\
\text { control of nausea and vomiting in cancer patients } \\
\text { after surgery. }\end{array}$ \\
\hline $\begin{array}{l}\text { Kurz et al., } \\
\text { 2012 }\end{array}$ & 62 & $\begin{array}{l}\text { Men with lung cancer at different ages } \\
\text { who require surgery. }\end{array}$ & $\begin{array}{l}\text { Case- } \\
\text { control }\end{array}$ & $\begin{array}{l}80 \% \text { oxygen prescription during surgery and 6 } \\
\text { hours after surgery, has had high impact and con- } \\
\text { trol of nausea and vomiting in cancer patients }\end{array}$ \\
\hline
\end{tabular}

Table 4. Effect of Gas on Post-Operation Nausea and Vomiting in Cancer Patients

\begin{tabular}{|c|c|c|c|c|}
\hline Authur & $\begin{array}{l}\text { Sample } \\
\text { size }\end{array}$ & Design/population & method & Outcome \\
\hline $\begin{array}{l}\text { Stoeliting et } \\
\text { al., } 2002\end{array}$ & 570 & $\begin{array}{l}\text { Candidate Patients undergoing } \\
\text { surgery with age wise \& sex } \\
\text { wise }\end{array}$ & $\begin{array}{l}\text { Clinical } \\
\text { Trial }\end{array}$ & $\begin{array}{l}\text { less Nausea and vomiting in patients in halothane than } \\
\text { isoflurane }\end{array}$ \\
\hline $\begin{array}{l}\text { Kumkeaw, } \\
2005\end{array}$ & 450 & $\begin{array}{l}\text { Candidate Patients undergoing } \\
\text { surgery with age wise \& sex } \\
\text { wise }\end{array}$ & $\begin{array}{l}\text { Clinical } \\
\text { Trial }\end{array}$ & $\begin{array}{l}\text { less Nausea and vomiting in patients in halothane than } \\
\text { isoflurane }\end{array}$ \\
\hline $\begin{array}{l}\text { Gaur et al., } \\
2005\end{array}$ & 210 & $\begin{array}{l}\text { Candidate Patients undergoing } \\
\text { surgery with age wise \& sex } \\
\text { wise }\end{array}$ & $\begin{array}{l}\text { Clinical } \\
\text { Trial }\end{array}$ & $\begin{array}{l}\mathrm{N} 2 \mathrm{O} \text { did not increase the incidence of nausea and } \\
\text { vomiting after surgery }\end{array}$ \\
\hline $\begin{array}{l}\text { Mathiv et al., } \\
2006\end{array}$ & 115 & $\begin{array}{l}\text { Candidate Patients undergoing } \\
\text { surgery for over } 35 \text { years in } \\
\text { both sexes. }\end{array}$ & $\begin{array}{l}\text { Clinical } \\
\text { Trial }\end{array}$ & $\begin{array}{l}\text { The combination of propofol and } \mathrm{N} 2 \mathrm{O} \text { had stressed } \\
\text { on increasing incidence of nausea and vomiting as- } \\
\text { sociated with } \mathrm{N} 2 \mathrm{O}\end{array}$ \\
\hline $\begin{array}{l}\text { sohajil et al., } \\
2006\end{array}$ & 75 & $\begin{array}{l}\text { Candidate Patients undergoing } \\
\text { surgery with age wise \& sex } \\
\text { wise }\end{array}$ & $\begin{array}{l}\text { Descrip- } \\
\text { tive }\end{array}$ & $\begin{array}{l}\text { N2Ohad increased incidence of nausea and vomiting } \\
\text { but had no effect on the incidence of vomiting. }\end{array}$ \\
\hline $\begin{array}{l}\text { Perreault et } \\
\text { al., } 2007\end{array}$ & 120 & $\begin{array}{l}\text { Candidate Patients undergoing } \\
\text { surgery with age wise \& sex } \\
\text { wise }\end{array}$ & $\begin{array}{l}\text { Clinical } \\
\text { Trial }\end{array}$ & $\begin{array}{l}\text { Addition of inspired oxygen (FIO2) during surgery } \\
\text { reduced the incidence of post operation of nausea and } \\
\text { vomiting }\end{array}$ \\
\hline $\begin{array}{l}\text { Normandin et } \\
\text { al., } 2005\end{array}$ & 65 & $\begin{array}{l}\text { Cancer patients undergoing } \\
\text { surgery, 20-65 years }\end{array}$ & $\begin{array}{l}\text { Clinical } \\
\text { Trial }\end{array}$ & $\begin{array}{l}\text { consumption of } \mathrm{N} 2 \mathrm{O} \text { by } 50 \text { percent with oxygen and } \\
\text { halothane MAC } 1 \text { did not increase with comparison } \\
\text { by MAC } 5 / 1 \text { halothane nausea and vomiting after } \\
\text { surgery }\end{array}$ \\
\hline $\begin{array}{l}\text { Toyooka, } \\
2012\end{array}$ & 33 & $\begin{array}{l}\text { Candidate Patients undergoing } \\
\text { surgery with age wise \& sex } \\
\text { wise }\end{array}$ & $\begin{array}{l}\text { Case- } \\
\text { control }\end{array}$ & $\begin{array}{l}\text { Post operation of nausea and vomiting in cancer pa- } \\
\text { tients has been more effective than Halothane. }\end{array}$ \\
\hline $\begin{array}{l}\text { Koerschgen et } \\
\text { al., } 2013\end{array}$ & 72 & $\begin{array}{l}\text { Cancer patients undergoing } \\
\text { surgery over } 12 \text { years in both } \\
\text { sex groups }\end{array}$ & $\begin{array}{l}\text { Case- } \\
\text { control }\end{array}$ & $\begin{array}{l}\text { Effects have not had any significant difference of } \\
\text { enflurane than desflurane with group control in nausea } \\
\text { and vomiting in cancer patients after surgery }\end{array}$ \\
\hline
\end{tabular}

\section{Effect of Oxygen Therapy on Post Operation of Nausea and Vomiting in Cancer Patients}

Today oxygen therapy for prevention of post operation of nausea and vomiting get the center of researcher's attention. And it considered in different masks with different percentages in different types of surgery diseases in order to be aware of the other possibility for patients with various disease.

Many hypotheses have been proposed about the mechanism of action of oxygen in the prevention of nausea and vomiting that the most acceptable of them 
was reduction in blood pressure and ischemic bowel or intestinal manipulation which could cause to release toxic substances such as serotonin. The mechanism could be true in explaining the antiemetic effect of oxygen in surgical manipulation and pressure within the abdomen due to intestinal ischemia that may occur. Other factors have been proposed to reduce the effect of oxygen, on decreasing dopamine which caused to control of nausea and vomiting (Golfam, 2009). Studies have shown that the prescription of 80 percent oxygen during the surgery and 6 hours after surgery has reduced nausea and vomiting of after surgery in women with breast cancer, (Purhonen et al., 2003; Sinikka et al., 2003; Piper et al., 2006; Lindbohm et al., 2007). Gastric cancer, (Bynner et al., 2005) and cervical cancer (Kurz et al., 2012; Kreisarin et al., 2013). According to the studies reviewed in this section, it can be concluded that in surgery, especially in patients with cancer who were following the loss of fluid, resulting in hypotension and the other hand with open abdomen and irritable bowel, using high oxygen can led to reduce in nausea and vomiting, especially in the recovery room. Also has found that oxygen supplementation continued intermittently until 6 hours after surgery for cancer patients can caused better results depending on the type of cancer. It should be noted that in order to had a better understanding about the mechanisms of oxygen on nausea and vomiting in cancer patients, further studies have performed the different types of cancer surgery on patients in different groups (Table 3).

\section{Effect of gas on post operation of nausea and vomiting in cancer patients}

Drugs used for general anesthesia were either for intravenous induction or anesthesia, by inhalation used to maintain anesthesia. Already a gas (nitrous oxide) and four inhaled anesthetics (halothane, isoflurane, enflurane, desflurane) have been commonly presented as an inhalation anesthetic. These differences were based on their physical, chemical and pharmacological. Since, in general anesthesia central nervous system was affected. The main complaint of patients are include nausea, headache, dizziness, blurred vision, Impaired balance, and sleep disorders are mental changes, Which sometimes lasted for several days after surgery, which can decrease the activity of cancer patients and Especially activities that require alertness accuracy and completeness (Miller, 2005). In the current study we examined, the most commonly used anesthetic gases and their effects on nausea and vomiting in cancer patients.

Halothane and isoflurane were both with the same mechanism causing headaches. Although they did not make a significant difference but headaches and nausea were more common in isoflurane (Cupta et al., 2004; Wang et al., 2014).

But the duration of headache and nausea in halothane was less than isoflurane that it was a significant difference. It seems that the vascular effects, increased intracranial pressure of brain and metabolic control was more inconsistent for the use of isoflurane. Although some of the useful properties of isoflurane were higher as the more power relaxant and low irritation and activation of central nervous system and rapid induction of anesthesia in comparison with halothane; but the prevalence of headache is more in isoflurane than halothane, which can lead to complaints and dissatisfaction of patients. Halothane had fewer effects on the digestive system and increased in blood pressure and lower visceral increased ICP may explain less of nausea and vomiting that compared with using halothane than isoflurane. The amounts of post operation nausea and vomiting have reported that cancer patients under anesthesia with halothane gas were less than isoflurane (Stoeliting et al., 2002; Kumkeaw, 2005; Toyooka, 2012). In studies that determined to survey the nausea. And also in comparison study the effects of using Enflurane has named in comparison with des flora to prevent nausea and vomiting in cancer patients after surgery. These two drugs in post operation of nausea and vomiting in cancer patients were not significantly different than in the control group (Koerschgen et al., 2013). N2O did not increase incidence of post operation nausea and vomiting in cancer patients (Ulla, 2006). In another study the effects of existing in recovery has emphasized the consumption of propofol and combination of propofol and $\mathrm{N} 2 \mathrm{O}$ on increasing incidence of nausea and vomiting induced N2O (Mathiv et al., 2006). In a study in which has concluded on the comparison of incidence of nausea and vomiting induced by intravenous and inhaled anesthetic that the $\mathrm{N} 2 \mathrm{O}$ had increased incidence of nausea and vomiting, but has not had any effect on the incidence of vomiting (Sohajil et al., 2006; Zahrina et al., 2014).

\section{Conclusions}

In this review we had examined recent studies of drug treatment oxygen therapy, medical gases and relaxation therapies for the prevention and controlling of post operation of nausea and vomiting in cancer patients. Finally, we concluded the analysis methods as amount of relaxation methods used to prevent nausea and vomiting caused by surgery depended on the type of cancer and surgery which has had done on the body, massaging different parts of the body decrease both nausea and vomiting, and in terms of physical and mental health of patients have had The best results and also without any adverse effects. And also among existing medical methods for reducing nausea and vomiting in cancer patients, prescription of dexamethasone has reduced post operation nausea and does not have any special side effects than existing drugs. We have concluded that the use of oxygen therapy with high concentrations of oxygen could have acceptable result in the aforementioned subject, for example, $80 \%$ during operation and 6 hours after surgery in cancer patients. In discussing the effect of gas as it is possible is better to use Halothane gas and if they need assumption of $\mathrm{N} 2 \mathrm{O}$ gas it is better to use combination of gas with a percentage of oxygen.

The conclusion of this study was as follow that the best choice for the control of nausea and vomiting in cancer patients during surgery and 6 hours after that is the use of oxygen with high concentration and also among the gases halothane and nitrok side in combination with oxygen and among the drugs dexamethasone recommend to use for 
controlling nausea and vomiting after surgery in cancer patients. Due to the excellent results of using massage therapy recommend in terms of reducing the incidence of nausea and vomiting as well as a great impact on mental health patients at certain hours of the day either before surgery or after surgery, depending on the type of cancer and surgery.

\section{References}

Ayala M, Celebi T, Uzun B, Freitag Y (2012). Effects of comparison of premedication with clonidine and midazolam combined with TCI for orthopaedic shoulder surgery. Anasthesiol Intensiv Med Notfallmed Schmerzther, 23, 56-86.

Bhatnagar S, Mishra S , Gupta M, Singal AK (2005). Effect of different concentrations of intraoperative supplemental oxygen on postoperative nausea and vomiting(PONV) in patients undergoing radical mastectomy. Intern $J$ Anesthesiol, 9, 120.

Brandt F, Singh V, Franck Y (2005). Effect of managing the multiple cause of PONV in the patient with cancer. Cancer Nursing, 37, 54-67.

Bynner B, Stegen N, Smeltzer P (2005). Ondansetron is no more effective than supplemental intraoperative oxygen for prevention of postoperative nausea and vomiting. Anesthesiology, 76, 54-63.

Canbay R, Muller F (2013). Effect of intravenous midazolam premedication on postoperative nausea and vomiting In cancer patients. Biosci Trends, 11, 5-72.

Chen MS, Hong CL, Chung HS, et al (2006). Dexamethasone effectively reduces postoperative nausea and vomiting in a general surgical adult patient population. Chang Gung Med $J, 29,175-81$.

Coskun F, Palomar Z (2013). Comparison clonidine and Metoclopramide on postoperative nausea and vomiting in cancer patients. Eur J Anaesthesiol, 21, 76-118.

Cupta A, Stierer T, Zuckerman R, Sakima N, Parker SD (2004). Comparison of recovery profile after ambulatory anesthesia with Propofol, Isoflurane, Sevoflurane and Desflurane: a systematic review. Anesth Analg, 98, 632-410.

Denehy P, Guinn S, silver W (2005). Granisetron/dexamethasone combination for reducing nausea and vomiting during and after spinal anesthesia for cesarean section. Anesth Analg, 41, 67-98.

Dietrich M, Castro A, Tauro J (2011). Subhypnotic doses of Betamethasone prevent postoperative nausea and vomiting In cancer patients. Middle East J Anesthesiol, 42, 65-73.

Ekangaki F, Chung R (2005). Gastrointestinal pharmacology. In: Bovill JG, Howie MB (editors). Clinical pharmacology for anaesthetists. $1^{\text {st }}$ edition. London: WB Saunders; pp.16-98.

Gan TJ (2006). Risk factor for postoperative nausea and vomiting. Anesth Analg, 102, 1884-98.

Gaur F, Gupta L (2005). Nitrous oxide dose not increase vomiting in children after myringotomy. Can J Anesth, 13, 176-88.

Golfam w, Golfam P, Golfam B (2009).The effect of excess oxygen in reducing nausea and vomiting after breast surgery. Sci Med Univers Ilam Winter, 17, 31-5.

Habib AS, Itchon-Ramos N (2004). A survey of postoperative nausea and vomiting. Anesthesia, 4, 67-85.

Harter RL (2002). Postoperative nausea and vomiting: prevention and therapy. Curr Opin Anaesth, 13, s469-73.

Hickok L, Yeung WS (2012). Effect of massage on nausea and vomiting in patients post anxiety. Cancer Nurs, 19, 76-87.

Houston P, Scholes C (2004).Foot massage: A nursing intervention to modify the distressing symptoms of pain and nausea in patients hospitalized with cancer. Cancer Nursing, 54, 156-68.

Isik D, Dietrich F, Castro S, Miao U (2013). Betamethasone effectively reduces postoperative nausea and vomiting in cancer patients. Chang Gung Med J, 6, 95-119.

Jaakkola JJ, Flak B, Gupta V (2009). Effect of supplemental oxygen reduce the incidence of postoperative nausea and vomiting. Anesth Analg, 54, 59-68.

Kearney N, Sripramote M, Petchpaisit N (2012). Effect of water massage on nausea and vomiting in patients post anxiety. Eur J Oncol Nurs, 32, 52-63.

Kim F, John S, Schmoll HJ (2013). Effect of acupressure on chemotherapy-induced nausea and vomiting in cancer patients post anxiety. Eur J Oncol Nurs, 18, 5-17.

Korjuo L, Youn S, Miller F, et al (2010). Evaluation of three risk scores to predict postoperative nausea and vomiting. Acta Anesthesiol Scand, 5, 45-6.

Koerschgen M, Hendrata S (2013). Effect of analysis of postoperative nausea and vomiting with enflurane and desflurane. Br J Anaesth, 24, 4-10.

Kreisarin Th, Baker RA (2013). Supplemental oxygen and the incidence of post anxiety nausea and vomiting in patients. Rev Bras Anestesiol, 33, 234-45.

Kurz A, Zimmer C (2012). Effects oxygen therapy in the incidence of postoperative nausea and vomiting in patients. Anesth Analg, 31, 23-35.

Kumkeaw P (2005). Day-case surgery: problem related to recovery. Br J Anesth, 65, 87-98.

Lapoint D, Kuhly P, Robertson K (2006). Effects of relaxation to reduce PONV induced by chemotherapy. Supportive Cancer Therapy, 14, 78-95.

Lefebvre A (2005). Effect of relaxation, imaging on PONVin brass cancer. Cancer Nursing, 13, 178-87.

Lindbohm S, Hirvonen A (2007). Effect of supplemental oxygen reduce the incidence of postoperative nausea and vomiting. Anesth Analg, 14, 97-116.

Madan R, Bhatia A, Chakithandy S, et al (2005). Prophylactic dexamethasone for postoperative nausea and vomiting in pediatric strabismus surgery: a dose ranging and safety evaluation study. Anesth Analg, 100, 1622-6.

Marro G, Bijuri T (2006). Dexamethasone decreases epidural morphine-related nausea and vomiting. Anesth Analg, 54, 78-85.

Mathiv M, Jonkins P (2006). A meta analysis of nausea and vomiting following maintenance of anesthesia with propofol or inhalational agents. Eur J Anesthesiol, 64, 54-91.

Miller DR (2005). Anestheia. $6^{\text {th }}$ ed. New York: Churchill Livingstone; 1-50, 105-155.

Normandin N, Rohm KD (2005). Adjusting oxygen use to reduce postoperative nausea, Eur J Anesthesiol, 34, 231-41.

Nortcliffe SA, Shah J, Buggy DJ (2003). Prevention of postoperative nausea and vomiting after spinal morphine for Caesarean section: comparison of cyclizine, dexamethasone and placebo. Br J Anaesth, 90, 665-70.

Perreault L, Tramer M (2007). Mcquay H, Omitting nitrous oxide in general anesthesia. Br J Anesth, 11, 25-45.

Piper SN, Rohm KD, Boltd J, Faust KL (2006). Inspired oxygen fraction of 0.8 compared with 0.4 does not further reduce postoperative nausea and vomiting in dolasetron-treated patients undergoing laparoscopic cholecystectomy. $\mathrm{Br} \mathrm{J}$ Anaesth, 97, 647-53.

Purhonen S, Niskanen M, Wustefeld M (2003). Supplemental oxygen for preventation of nausea and vomiting after breast surgery. Br J Anaesth, 91, 284-7.

Ratehanon S, Morrow GR, Wiriysirivej B (2011). The effect of relaxation intervention on nausea and vomiting in patients post anxiety. Support Care Cancer, 21, 34-57. 
Rowbotham DJ (2005). Recent advances in the nonpharmacological management of postoperative nausea and vomiting. Br J Anaesth, 95, 77-81.

Ruthstrom R, Tonner H (2012). Effects of clonidine on postoperative nausea and vomiting in breast cancer patients. Anesthesiology, 53, 43-56.

Sinikka P, Matti T, Ulla R (2003). Supplemental oxygen does not reduce the incidence of postoperative nausea and vomiting after ambulatory gynecologic laparoscopy. Anesth Analg, 96, 91-6.

Sohajil A, Hanisa B 2006. Effects of a comparison of the incidence of postoperative nausea and vomiting after propofol fentanyl anesthesia and that ofter nitrous oxide anesthesia. Masui, 4, 14-25.

Stoeliting PK, Dierdorf SF (2002). Anesthesia \& Co-Existing Disease. $4^{\text {th }}$ ed. New York: Churchill livingstone: 233-299.

Toyooka H (2012). Effects of halothane and enflurane in the incidence of postoperative nausea and vomiting in patients. Chang Gung Med J, 19, 106-52.

Ulla R (2006). meta analysis of nausea and vomiting following maintenance of anesthesia with propofol or inhalational agents. Eur J Anesthesiol, ??, 65-76.

Vigil G, Dom L (2012). Midazolam: an effective antiemetic after Surgery in cancer patients-a clinical trial. Anesth Analg, $\mathbf{5 4}, 339-43$

Viswanathan M, Eisenberg Z (2006). Relaxation to reduce nausea, vomiting and anxiety induced by chemotherapy in Japanese patients. Cancer Nursing, 54, 245-56.

Wakim L, Radtke S, Gaur F (2006). Effects of dexamethasone on decreases PONV after adenotonsilectomy. Am J Emerg Med, 5, 45-65.

Wang S-Y, Yang Z-J, Zhang L (2014). Olanzapine for preventing nausea and vomiting induced by moderately and highly emetogenic chemotherapy. Asian Pac J Cancer Prev, 15, 9587-92.

Zahrina AK, Norsa' adah B, Hassan NB, et al (2014). Adherence to capecitabine treatment and contributing factors among cancer patients in Malaysia. Asian Pac J Cancer Prev, 15, 9225 . 